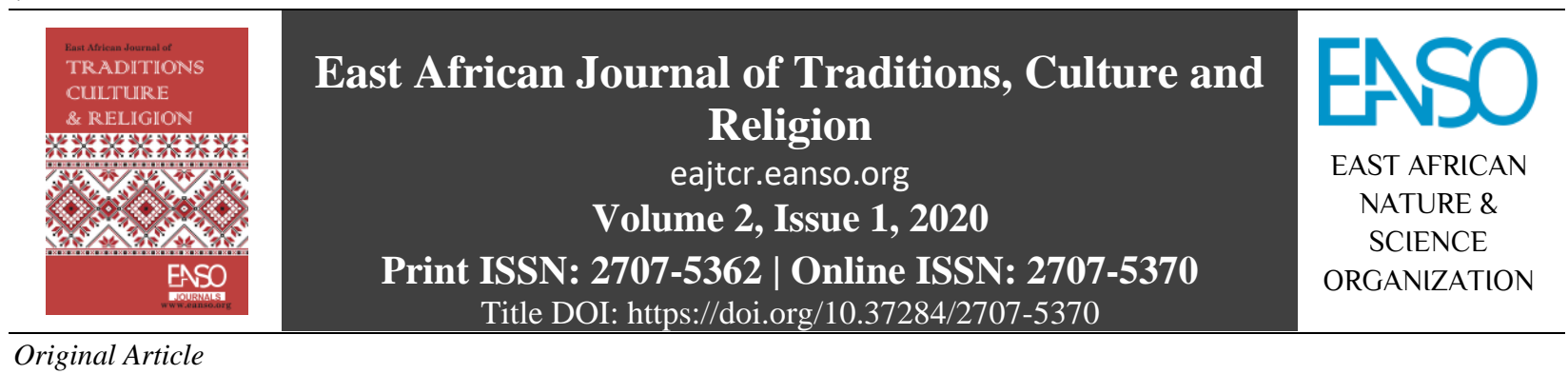

\title{
The Impact of Cultural Beliefs on Mental Health: A World View from Selected Communities in Western Kenya
}

\author{
Caroline Noel Amunga ${ }^{*}$ \\ ${ }^{1}$ Department of Social Sciences Education, Masinde Muliro University of Science and Technology, Kakamega, Kenya. \\ *Correspondence Email: carolinenoelamunga@gmail.com
}

Article DOI: https://doi.org/10.37284/eajtcr.2.1.21

Date Published:

26 August 2020

\section{ABSTRACT}

Mental health has been discussed in several accounts, especially from the

Keywords: western worldview. It has always existed even before civilization. The main objective of this paper is to assess the impact of cultural beliefs on mental health

Anxiety, among selected communities in Western Kenya. This paper was guided by the Cultural Beliefs, Mental Health, Social Behaviour,

Western Kenya,

Trauma. social psychology theory which posits that social influences, perception and interaction are vital in understanding social behaviour (Krech \& Crutchfield, 1948). The paper adopted the descriptive survey design to present data thus studying the situation as it is in an attempt to explain it (Hancock, Ockleford \& Windridge, 2001). The sampling techniques were Purposive which was used to select the specialists. The study instruments were the interview schedule, Focus Group Discussion and Document review. The validity of the instruments was established through content validity by experts from Masinde Muliro University Science and Technology (MMUST). This paper established that cultural beliefs have both a negative and positive impact on mental health in the sense that anxiety and trauma from broken taboos and norms led to mental illness whereas the performance of rituals brought about peace and psychological contentment, hence, mental health. This paper recommends that cultural beliefs which lead to mental health should be preserved for the particular purpose. This paper shall add more information to the existing pool of knowledge.

\section{APA CITATION}

Amunga, C. (2020). The Impact of Cultural Beliefs on Mental Health: A World View from Selected Communities in Western Kenya. East African Journal of Traditions, Culture and Religion, 2(1), 34-38. https://doi.org/10.37284/eajtcr.2.1.21

\section{CHICAGO CITATION}

Amunga, Caroline. 2020. "The Impact of Cultural Beliefs on Mental Health: A World View from Selected Communities in Western Kenya". East African Journal of Traditions, Culture and Religion 2 (1), 34-38. https://doi.org/10.37284/eajtcr.2.1.21.

\section{HARVARD CITATION}


Amunga, A. (2020) "The Impact of Cultural Beliefs on Mental Health: A World View from Selected Communities in Western

Kenya”, East African Journal of Traditions, Culture and Religion, 2(1), pp. 34-38. doi: 10.37284/eajtcr.2.1.21.

\section{IEEE CITATION}

C. Amunga, "The Impact of Cultural Beliefs on Mental Health: A World View from Selected Communities in Western Kenya", EAJTCR, vol. 2, no. 1, pp. 34-38 Aug. 2020.

\section{MLA CITATION}

Amunga, Caroline. "The Impact of Cultural Beliefs on Mental Health: A World View from Selected Communities in Western Kenya." East African Journal of Traditions, Culture and Religion, Vol. 2, no. 1, August 2020, pp. 34-38, doi:10.37284/eajtcr.2.1.21.

\section{INTRODUCTION}

According to Nordquist (2017), mental health is cognitive, behavioural and emotional wellbeing. It is about how we think, feel, and behave. The term "mental health" is sometimes used to mean an absence of a mental disorder (Fayyad et. al., 2017). World Health Organization (WHO) defines mental health as a state of well-being in which the individual realizes his or her abilities, can cope with the normal stresses of life, can work productively and fruitfully, and is able to contribute to his or her community (Amuyunzu-Nyamongo, 2013). The reverse of the above definitions is mental illness. There are still many more definitions but they all point to one being mentally unstable.

Mental health can affect daily life, relationships, and even physical health. Mental health also includes a person's ability to enjoy life and to attain a balance between life activities and efforts to achieve psychological reliance. It affects people of any age (Thabede, 2008).

\section{METHODOLOGY}

The methodology involved meta-synthesis and interviews. This method involves the analysis of published materials and interviewing specialists on mental health and cultural beliefs (Glaser ,1978).

\section{DISCUSSIONS}

Culture is the totality of socially transmitted behaviour patterns arts, beliefs, institutions and all other products of human work and thought (O'Toole, 2002). Culture is learned and shared within social groups and is transmitted by nongenetic means. According to Spencer-Oatey and Franklin (2012), culture is that complex whole which includes knowledge, belief, art, morals, law, custom and any other capabilities and habits acquired by man as a member of the society.

\section{CAUSES OF MENTAL ILLNESS ACCORDING TO CULTURE}

Mental illness is seen as a calamity in the African countries and especially the Luhya of western Kenya. It has always existed even before civilization and also before science with its medical care and medical cure. It has varied and distinct well explained causes amongst African communities. These causes can be categorized into causes from the unseen world, breaking rules, punishment, witchcraft, ancestral curses, nature and even hit backs for committing evil (Ventevogel et. al., 2013).

\section{Breaking Rules}

The African societies have ethics which help maintain law and order by adhering to given rules and regulations. These rules and regulations come in the form of taboos which contain the dos and don'ts of a given people. This implies that most Africans are subjected to a choice between the good that should be done and the evil that should be avoided. The former is normally rewarded but the later has consequences. The moral code should be observed strictly. Breaking some of these rules may earn one mental illness and or a member of his family, especially children. Such a taboo may include incest and killing a human being which was considered an abomination. The direct culprit would directly suffer from mental illness or his children would pay for him through the same mental illness as he suffered the pain and strain of nursing. If not, someone from his direct lineage would pay through mental illness. 
Rules and regulations were also observed during rituals. Every culture has its specialists and their definite roles which have to be strictly adhered to. Compromise on some of these rules would cause mental illness. An example is offering sacrifice to a god to which you are not a priest. Another is meeting a spirit and looking directly at it. These spirits were masked human beings but very revered, especially when adorned in the ceremonial or rather ritual regalia. Women are forbidden to meet the Bukusu circumcisers and their entourage one point during the circumcision rituals. If a woman breaks this rule, she is likely to suffer from mental illness.

The specialists in society had the mandate of giving instructions according to the requirements of their office. Such specialists include magicians, priests and advisors. They all represent the mysterious worlds and spoke on their behalf. They represented the deity in different capacities. Failure to adhere to their instructions and counsel would lead to calamities that included mental illness. Disobeying the specialists was as good as disobeying the deity and declaring war with the unseen world (Njenga, 2007).

\section{The Unseen World}

The unseen world includes gods, spirits, ancestors and the living dead. All these have a say in the world of the living and influence it in one way or the other, either positively or negatively depending on the treatment they receive from the world of the living. They are also capable of punishing the living by striking them with calamities such as mental illness depending on the offences committed. Mental illness falls in the category of serious punishments for grievous offences. Such offences include murder, neglecting rituals and failure to offer sacrifices. This, therefore, points to the fact that the unseen world was very much alive in the world of the living (Ndlovu, 2016).

\section{Hit Backs on Evil People}

In the African culture, there is always good magic and bad magic. Good magic is used to protect the society and fight off evil. Bad magic, on the other hand, is used by bad people to harm the innocent or for selfish gain. Bad magic against good people would sometimes backfire on the evil people in an act of God with misfortunes such as mental illness striking bad people who bring evil on innocent unsuspecting people. It is believed that it is the deity's way of protecting his good people (Kramer, Kwong, Lee \& Chung, 2002).

\section{Witchcraft}

Prosperous people would earn Jealousy from evilhearted people thus attracting their wrath. The latter would enlist the help of witches, sorcerers or magicians to bewitch the target. Sometimes good people would be struck with a tormenting mental illness or alternatively a very close relative under their care (Teferra \& Shibre, 2012).

\section{Punishment}

Mental illness would directly be punishment for grievous sins or evil like incest and rape. Grievous mistakes called for grievous punishments. To this end, people in the African societies dared not to sin; not even in secrecy because it would be revealed in broad daylight through mental illness (Behere, 2013).

\section{Evil Spirits}

The spirits of bad people who never lived right during their lifetime hovered around and tormented the living. Evil spirits would enter into the living and manifest through insanity. Such evil people would not be named and they would take offence thus bringing evil to the society (Ndlovu, 2016).

\section{Nature}

Nature was also considered as a cause of mental illness. Such nature includes thunder, lightning or rivers. Rivers were dwelling places of gods. They had shrines and were thus to be treated in a special way and with respect. They were to be revered. Failure to which one would meet the gods' wrath. Shock from thunder and lightning would cause one to go berserk. Sometimes it would be ascribed to the deity's anger or just a normal misfortune (Schmidt, 2007).

\section{Stress}

People who committed offences got tormented psychologically even when nobody knew about it. 
There would be the fear that sooner or later the gods would be hot on their heels baying for their blood. Such stress would degenerate into depression and instability mental wise. This is a self-inflicted slow poison (Rosiek et. al., 2016).

\section{REMEDY}

Just as it is in the scientific medical world, there is no one way that one can remedy mental illness or deal with it. There are as many varied ways as there are causes. The remedy depends on the cause and prescription from the unseen world through the specialists who may include diviners and priests. They could consult the world of the dead and come up with a remedy. The remedies would include appeasing the gods, spirits, ancestors and the living dead. Appeasing entailed offering of prescribed sacrifices and offerings. The sacrifices were very particular, deliberate and specific for example in the choice of the type of sacrifice, the colour, sex and age. The specifications were to be followed to the latter for the sacrifice to be effective.

Offerings would include the pouring of libation. All these usually would be accompanied by the performance of rituals. The rituals included a cleansing ceremony amongst the Abatsotso of western Kenya. The ceremony would be elaborate with song, dance and chants. The type of songs and dances themselves would tell you the kind of ritual that would be taking place. When offering sacrifices, libation would also be poured to appease the spirits of the dead. Sacrifices included slaughtering specific animals based on the weight of the mistake or the sin committed. They included white or black chicken among the Abawanga. Other animals include cows, goats and sheep and even human beings (Edgerton, 1980).

Magic was also an essential remedy. There was good magic which was used for the good of the people or the community at large by protecting them or warding off evil. Good magic like the one among the Banyala would exorcise mental illness out of patients. In turn, the sufferer upon healing would be given protective charms to wear especially around the wrists, ankles, and waist. This would ward off 'evil eyes' which included witches and bad marauding spirits of the dead.
Witch doctors also played an important role in providing remedies for mental illness. They would prescribe herbs according to the cause of the problems. The herbs could be administered periodically amongst the Abamarama of western Kenya. The very herbs would be made into concoctions whose steam would be inhaled like among the Abashisa people. Some concoctions would be taken orally in liquid form or ashes. Some ashes found their way into the body through cuts and incisions which would make artistically on the body of the sick in very particular places as I found out from the Abatsotso. Some concoctions would be bathed with or applied on particular parts of the body. Some concoctions would be sprinkled in the victims' compound or even around the house (Sorsdahl et. al., 2009|).

In response, the gods and spirits would have mercy and reverse the situation and sanity would be restored. In some cases, the patient would have to live with the situation because it was an irreversible curse or a generational curse. Another reason why one would have to live with mental illness was when it was a punishment on him or her directly for a taboo he or she broke or when the parents had committed sin. These sins would be in the public domain or private (Mbiti, 1969).

\section{CONCLUSION}

Mental illness has always been part and parcel of the African society. Culture had its own way of dealing with the calamity which in turn brought about acceptance, calmness, patience and even restoration to sanity. Nobody dared break a taboo. Everyone tried not to be on the offensive for fear of this calamity of mental illness. To this end, mental illness remedies gave hope that all would be well and brought about peace in one's heart.

The African way of dealing with mental illness had a positive side like putting a check on people's morals, behaviour and conduct. It should not be wholly discarded but modified to assist in dealing with the challenges of mental illness. 


\section{REFERENCES}

Amuyunzu-Nyamongo, M. (2013). The social and cultural aspects of mental health in African societies. Commonwealth health partnerships, 2013, 59-63.

Behere, P. (2013). Anweshak Das, Richa Yadav, and Aniruddh P. Behere."Religion and Mental Health.”. Indian Journal of Psychiatry, 55.

Edgerton, R. B. (1980). Traditional treatment for mental illness in Africa: A review. Culture, Medicine and Psychiatry, 4(2), 167-189.

Fayyad, J., Sampson, N. A., Hwang, I., Adamowski, T., Aguilar-Gaxiola, S., AlHamzawi, A., ... \& Gureje, O. (2017). The descriptive epidemiology of DSM-IV Adult ADHD in the world health organization world mental health surveys. ADHD Attention Deficit and Hyperactivity Disorders, 9(1), 47-65.

Glaser, B. G. (1978). Strauss (1967): The Discovery of Grounded Theory: Strategies for Qualitative Research. London: Wiedenfeld and Nicholson, 81, 86.

Hancock, B., Ockleford, E., \& Windridge, K. (2001). An introduction to qualitative research. Trent focus group.

Kramer, E. J., Kwong, K., Lee, E., \& Chung, H. (2002). Cultural factors influencing the mental health of Asian Americans. Western Journal of Medicine, 176(4), 227.

Krech, D., \& Crutchfield, R. S. (1948). Theory and problems of social psychology.

Mbiti, J. S. (1990). African religions \& philosophy. Heinemann.

Ndlovu, H. L. (2016). African beliefs concerning people with disabilities: implications for theological education. Journal of Disability \& Religion, 20(1-2), 29-39.

Njenga, F. (2007). The concept of mental disorder: an African perspective. World Psychiatry, 6(3), 166.
Nordquist, B. (2017). Literacy and mobility: Complexity, uncertainty, and agency at the nexus of high school and college. Routledge.

O'Toole, M. (2002). The relationship between employees' perceptions of safety and organizational culture. Journal of safety research, 33(2), 231-243.

Rosiek, A., Rosiek-Kryszewska, A., Leksowski, Ł., \& Leksowski, K. (2016). Chronic stress and suicidal thinking among medical students. International journal of environmental research and public health, 13(2), 212.

Schmidt, C. W. (2007). Environmental connections: a deeper look into mental illness.

Sorsdahl, K., Stein, D. J., Grimsrud, A., Seedat, S., Flisher, A. J., Williams, D. R., \& Myer, L. (2009). Traditional healers in the treatment of common mental disorders in South Africa. The Journal of nervous and mental disease, 197(6), 434.

Spencer-Oatey, H., \& Franklin, P. (2012). What is culture. A compilation of quotations. GlobalPAD Core Concepts, 1-22.

Teferra, S., \& Shibre, T. (2012). Perceived causes of severe mental disturbance and preferred interventions by the Borana semi-nomadic population in southern Ethiopia: a qualitative study. BMC psychiatry, 12(1), 79.

Thabede, D. (2008). The African worldview as the basis of practice in the helping professions. Social Work/Maatskaplike Werk, 44(3).

Ventevogel, P., Jordans, M., Reis, R., \& De Jong, J. (2013). Madness or sadness? Local concepts of mental illness in four conflict-affected African communities. Conflict and health, 7(1), 3. 